\title{
IMPACT OF ECONOMIC FACTORS ON MARKET VOLATILITY - A STUDY OF NSE INDIA
}

\author{
Dr. Mohammed Khaja Saber \\ Assistant Professor, Rukmini College of Management and Commerce, Ameerpet, \\ Hyderabad, Telangana, India.
}

\begin{abstract}
The present study has been focused on the economic factors impact on the market volatility. The study has considered the NSE India base index - Nifty from the period of 2009-10 to 2019-20. The study examined the impact of select economic factors on the Nifty volatility with the help of statistical method of ARCH model. The study result indicates that the GDP influence has been found higher compared with the IIP and Inflation on the Nifty volatility. The study examined the future movement of the economic factors, which are having the significant influence on the nifty volatility with the help of ARIMA. The study result reveals that the IIP will change constantly but inflation will be expected to go downwards in the coming future. This paper will be useful to the Equity Market Investors, Fund Managers, Regulators, Government stakeholders and Academic researchers.
\end{abstract}

Key words: ARCH, ARIMA, GDP, IIP, Inflation and Nifty Volatility

Cite this Article: Mohammed Khaja Saber, Impact of Economic Factors on Market Volatility - A Study of NSE India, International Journal of Management, 11(12), 2020, pp. 1611-1620.

http://iaeme.com/Home/issue/IJM?Volume=11\&Issue=12

\section{INTRODUCTION}

Rapid growth rates, growing sales levels and rising stock markets have led to India's -net worth of investors (HNIs) over the last two decades. This represented a higher number of investors investing in the stock markets. Nevertheless, not all investing activities of investors are guided by the same set of logical beliefs. Throughout search of diversification, investors with higher risk appetites would like to experiment and try out new and unusual strategies, whereas small investors are more geared towards less risky return-consistent investing. Investor decisions are informed by expected returns and their understanding of risk-related investment options. The theory of the judgment on economic investment describes the investment decision of the investor in terms of the macro-economic means. On the basis of the classical parameters of 
wealth making a choice over time between consumption and investment, individuals optimize their usefulness on the basis of the concept of microeconomic efficiency.

In this modern age, the stock exchange plays a dynamic role in the mobilization of longterm funds and the trading of shares. These stock exchanges are responsible for investment, capital establishment and also act as an Indian stock market health indicator. Since the economic liberalization of the stock market has seen a significant increase in the amount of trade showing progress on the stock market. A well-performing stock exchange plays a useful role in economic activity through growth and investment, efficient allocation of funds and attracting foreign direct investment.

Various studies on macro-economic variables have been conducted and the study reveals the long-term relationship between macroeconomic variables and market success. Naik (2013) explored the relationship between the Indian stock market index, industrial production indices, wholesale price index, money supply, treasury bills and exchange rates. In general, the output of the macro-economic stimulus variable stock market is both national and multinational. Several scholars have attributed macro-economic factors such as stock price variables such as industrial production, inflation rate, per capita income intake, oil price increase, risk premium, yield curve, cash supply and exchange rate, CPI, PPI, trade balance, employment index, monetary aggregate, gold price and silver price and business cycle.

It is well known that the Gross Domestic Product (GDP) is a monetary measure of the market value of all goods and services produced over a specified period of time. GDP rates typically assess the economic performance of the country concerned. On the other hand, a continuous increase in the general price level for goods and services is referred to as the inflation rate. The rise in inflation is leading to a higher supply of money. The change in demand curves to the left or the right means an increase or fall in the interest rate of the economy. As a result, such GDP growth, inflation, and interest rates will increase stock-return volatility, leading to high risk, and make investors move their investment to less risky portfolios.

From the comprehensive literature surveyed, the stock market plays a prominent role as an indicator of economic development in this global economy. The key objectives of this paper are to investigate the effect of the selected factors on NSE base index volatility-Nifty. Therefore, this report seeks to identify some of the macroeconomic (external) factors, such as GDP, inflation rate and IIP, which have an unwavering impact on the market price of NSE equities in India.

\section{REVIEW OF LITERATURE}

KaanCelebi et al (2019): This paper explores the effect of the 1991-2018 period on the main German stock index of macroeconomic conditions, German government bond yields, sentiment and other key indicators, The researcher also found that the delayed effect of the monetary aggregate of the M2 constituents on stock returns has changed the direction between the crisis and the post-crisis era. Overall, the results show that a greater number of factors and economic indicators had a significant impact on stock returns. This can be concluded that in the post-crisis era, the macro-driven market prevails.

Ashwani et al (2018): This paper says that since the advent of the endogenous growth paradigm, financial progress has been a focal point for policy makers and economists. The present study took the opportunity to capture the role of macro-economic variables in explaining stock market volatility in India using the MIDAS GARCH method. The study found that macroeconomic variables such as the exchange rate, the money supply, the treasury bills, net foreign direct investment and the stock investments had a predictable potential for stock market volatility.

RomiSainy (2016): This paper focused on economic liberalization, the volume of trade in stock exchanges has increased considerably, as is evident from the increase in stock indices. Growth 
in stock market operations was mainly due to an increase in the amount of investment opportunities available to retail investors, which suited their risk appetite and thus improved consumer interest in stock market operations. The aim of this paper is to examine brokers perceptions of the factors affecting Indian stock prices and thus to influence their investment decisions. The researcher identified seven factors affecting their investment decisions.

Kausik Chaudhuri (2009): This paper researches the volatility of stock returns in some Asian emerging markets in terms of the volatility of domestic and external factors. The paper found that both domestic macroeconomic variables and international variables are found to have explanatory power for stock return volatility. The evidence strongly suggests the presence of a significant effect and integration of capital markets in this region. This study document that the role of government in terms of fiscal and monetary policy in the smooth functioning of the economy, which reflects through the stock markets.

John J Binder (2006): This paper examines the ability of rational economic forces to explain the uncertainty of the stock market. The basic uncertain economic model defines four determinants of stock market volatility: price uncertainty, risk-free interest rates, the equity risk premium, and the projected profit-to-expect-revenue ratio. When the coefficients of regression differ by comparing clusters over time, more than $90 \%$ of the variance in market volatility is explained by four variables. The findings are useful in explaining the past behaviour of stock market volatility and predicting future volatility.

\section{OBJECTIVES OF THE STUDY}

- To examine the impact of select economic factors on the Nifty Volatility.

- To know the future movement of the Nifty based on the select economic factors

\section{HYPOTHESIS OF THE STUDY}

H0: There is no impact of select economic factors on the Volatility of nifty

\section{SCOPE OF THE STUDY}

The present study has been emphasized on the equity market volatility. The study has considered the economic factors and studied the NSE India base index - nifty from the period of 2009-10 to 2019-20. The study has considered the following economic factors from the RBI manual.

- Gross Domestic Production - GDP

- Index of Industrial Production - IIP

- Consumer price Index - Inflation

\section{RESEARCH METHODOLOGY}

The present study has considered the secondary data and applied the following statistical methods for the examination of framed objectives.

Auto Regressive Conditional Heteroskedasticity - ARCH: The study applied the ARCH model to know the impact of select economic factors on the Nifty Volatility.

Auto Regressive Integrated Moving Average - ARIMA: The study applied the ARIMA to know the future movement of the select economic factors, so that the Nifty movement can be predicted. 


\section{TABULATION OF DATA ANALYSIS}

\section{Objective1: To examine the impact of select economic factors on the Nifty Volatility.}

This objective made an attempt to identify the 10-year, (i.e. 2009-10 to 2018-19) change of economic factor on the Return market volatility. The Heteroskedasticity test was applied to identify the effect of ARCH between the economic factors with the return prices of Nifty. Residual graph shows the economic factor's graphic representation of return Nifty prices. Auto Regressive Conditional Heteroskedasticity was to check the effect of the economic factor on Nifty return prices volatility.

\section{Heteroskedatictiy of GDP to NIFTY}

The study applied the heteroskedasticity test to know the existence of volatility between the GDP and Nifty. The following hypothesis has been framed.

Null Hypothesis: No ARCH effect exist between the GDP and Return price of Nifty Alternative Hypothesis: ARCH effect exist between the GDP and Return price of Nifty

Table 1. Heteroskedatictiy of GDP to NIFTY

\begin{tabular}{|l|l|l|l|}
\hline \multicolumn{4}{|c|}{ Heteroskedasticity Test: ARCH } \\
\hline F-statistic & 7.983008 & Prob. F $(1,41)$ & 0.0023 \\
\hline Obs*R-squared & 1.006820 & Prob. Chi-Square(1) & 0.0027 \\
\hline
\end{tabular}

Source: Secondary Data

The above table -1 of Heteroskedasticity test indicated that F-statistic calculated value (7.983) seem to be greater than the critical value (4.0012) and p-value seems to be less than 0.05 which indicates that reject the Null Hypothesis and Accept Alternative hypothesis. Thereby confirming that ARCH effect exist between the changes in GDP with Return price of Nifty.

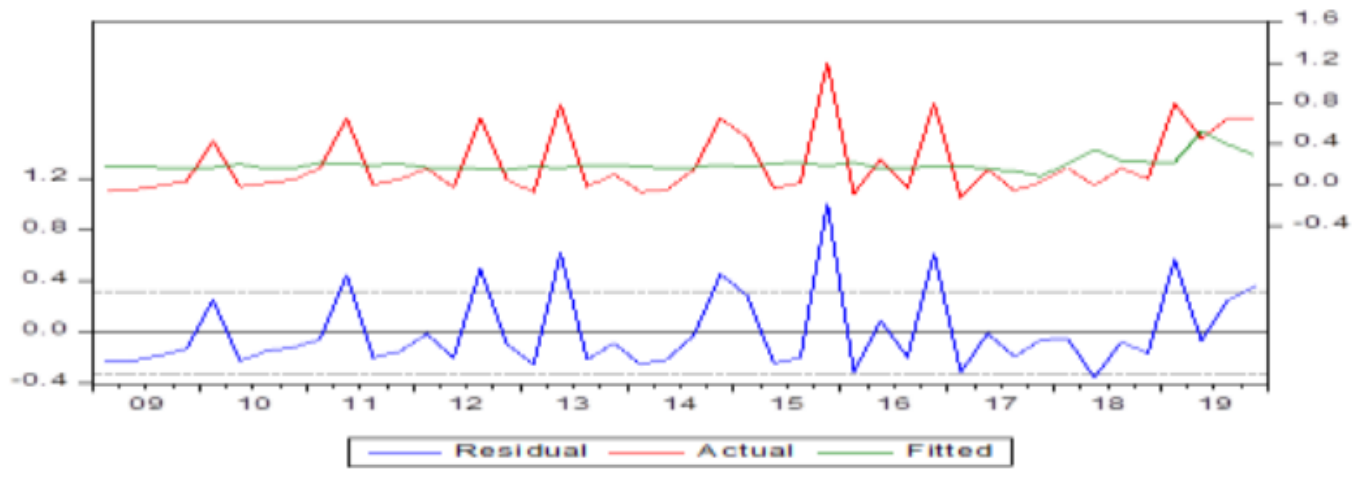

Figure 1. Residual Graph of GDP to Nifty

Source: Secondary Data

The above graph -1 reflects the change in GDP on return price of Nifty for the period of 10 years. It signifies from residual graph that GDP movement crossed the fitted lines which states that the volatility exists, as the volatility of one cluster is followed by the volatility of other cluster. Hence, the ARCH model can be applied to know the high or low volatility of the nifty with the changes in GDP. 
Table 2. ARCH effect of GDP to Nifty

\begin{tabular}{|c|c|c|c|c|}
\hline \multicolumn{5}{|c|}{ Dependent Variable: NIFTY } \\
\hline \multicolumn{5}{|c|}{ Method: ML ARCH - Normal distribution (BFGS / Marquardt steps) } \\
\hline \multicolumn{5}{|c|}{ Sample: 2009Q1 2020Q4 } \\
\hline \multicolumn{5}{|c|}{ Included observations: 48} \\
\hline \multicolumn{5}{|c|}{ Convergence achieved after 34 iterations } \\
\hline \multicolumn{5}{|c|}{ Coefficient covariance computed using outer product of gradients } \\
\hline \multicolumn{5}{|c|}{ Presample variance: backcast (parameter $=0.7$ ) } \\
\hline \multicolumn{5}{|c|}{$\operatorname{GARCH}=\mathrm{C}(3)+\mathrm{C}(4) * \operatorname{RESID}(-1)^{\wedge} 2$} \\
\hline Variable & Coefficient & Std. Error & z-Statistic & Prob. \\
\hline $\mathrm{C}$ & -0.029272 & 0.005530 & -5.293081 & 0.0000 \\
\hline GDP & 0.458053 & 0.078968 & 0.735144 & 0.0023 \\
\hline \multicolumn{5}{|l|}{ Variance Equation } \\
\hline $\mathrm{C}$ & 0.000647 & 0.000929 & 0.696300 & 0.4862 \\
\hline $\operatorname{RESID}(-1)^{\wedge} 2$ & 4.400972 & 0.719630 & 6.115601 & 0.0000 \\
\hline R-squared & 0.651694 & \multicolumn{2}{|c|}{ Mean dependent var } & 0.030002 \\
\hline Adjusted R-squared & -0.576734 & \multicolumn{2}{|c|}{ S.D. dependent var } & 0.192158 \\
\hline S.E. of regression & 0.199394 & \multicolumn{2}{|c|}{ Akaike info criterion } & 1.325706 \\
\hline Sum squared resid & 1.669832 & \multicolumn{2}{|c|}{ Schwarz criterion } & 1.163507 \\
\hline Log likelihood & 33.16554 & \multicolumn{2}{|c|}{ Hannan-Quinn criter. } & 1.265555 \\
\hline Durbin-Watson stat & 2.324017 & & & \\
\hline
\end{tabular}

Source: Secondary Data

The mean equation table -2 shows that the probability value seem to be less than $0.05(0.023$ $<0.05)$ implies that the model is significant. Similarly, variance equation observed to be significant at $5 \%$ level (i.e., p-value is $0.000<0.05$ ). The AIC-Akaike data criterion (1.325), the SC-Schwarz criterion (1.163) and the HQC-Hannan-Quinn criterion (1.265) indicated the criterion level of the model. Thereby confirming that the unit increase in GDP will increase the return price of nifty by 4.40 and concludes that the change in GDP has a significant effect on the volatility of the return prices of Nifty.

\section{Heteroskedatictiy of IIP to NIFTY}

The study applied the heteroskedasticity test to know the existence of volatility between the IIP and Nifty. The following hypothesis has been framed.

Null Hypothesis: No ARCH effect exist between the IIPand Return price of Nifty

Alternative Hypothesis: ARCH effect exist between the IIP and Return price of Nifty

Table 3. Heteroskedatictiy of IIP to NIFTY

\begin{tabular}{|l|l|l|l|}
\hline \multicolumn{5}{|c|}{ Heteroskedasticity Test: ARCH } \\
\hline F-statistic & 6.709047 & Prob. F $(1,41)$ & 0.0036 \\
\hline Obs*R-squared & 0.730993 & Prob. Chi-Square(1) & 0.0026 \\
\hline \multicolumn{4}{|c}{ Source: Secondary Data } \\
\hline
\end{tabular}

Table 3 depicts that F-statistic calculated value (6.709) seem to be greater than the critical value (4.0012) and p-value seems to be less than 0.05 which indicates that reject the Null Hypothesis and Accept Alternative hypothesis. Thereby confirming that $\mathrm{ARCH}$ effect exist between the changes in IIP with Return price of Nifty.

Figure 2 represents the change in IIP on return price of Nifty for the period of 10 years. It signifies from residual graph that IIP movement crossed the fitted lines which states that the volatility exists, as the volatility of one cluster is followed by the volatility of other cluster. 
Hence, the ARCH model can be applied to know the high or low volatility of the nifty with change in IIP.

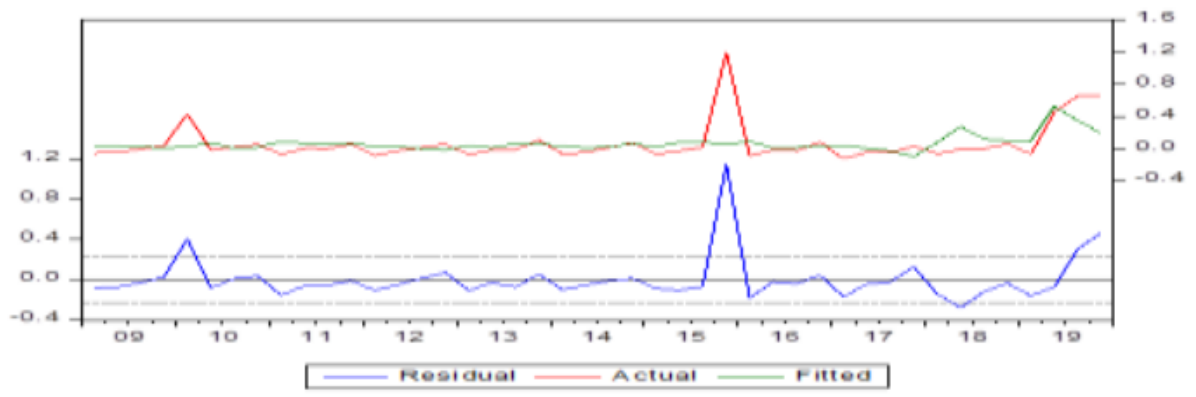

Source: Secondary Data

Figure 2. Residual Graph of IIP to Nifty

The mean equation table 4 depicts that the p-value is $0.005(<0.05)$ implies that the model is significant. Similarly, variance equation observed to be significant at $5 \%$ level (i.e., p-value is $0.000<0.05)$. The AIC-Akaike data criterion (1.382), the SC-Schwarz criterion $(1.220)$ and the HQC-Hannan-Quinn criterion (1.322) indicated the criterion level of the model. Thereby confirming that the unit increase in IIP will increase the return price of nifty by 3.723 and concludes that the change in IIP has a significant effect on the volatility of the return prices of Nifty.

Table 4. ARCH effect of IIP to Nifty

\begin{tabular}{|c|c|c|c|c|}
\hline \multicolumn{5}{|c|}{ Dependent Variable: NIFTY } \\
\hline \multicolumn{5}{|c|}{ Method: ML ARCH - Normal distribution (BFGS / Marquardt steps) } \\
\hline \multicolumn{5}{|c|}{ Sample: 2009Q1 2020Q4 } \\
\hline \multicolumn{5}{|c|}{ Included observations: 48} \\
\hline \multicolumn{5}{|c|}{ Convergence achieved after 25 iterations } \\
\hline \multicolumn{5}{|c|}{ Coefficient covariance computed using outer product of gradients } \\
\hline \multicolumn{5}{|c|}{ Presample variance: backcast $($ parameter $=0.7)$} \\
\hline \multicolumn{5}{|c|}{$\mathrm{GARCH}=\mathrm{C}(3)+\mathrm{C}(4)^{*} \operatorname{RESID}(-1)^{\wedge} 2$} \\
\hline Variable & Coefficient & Std. Error & z-Statistic & Prob. \\
\hline $\mathrm{C}$ & -0.029118 & 0.006579 & -4.425684 & 0.0000 \\
\hline IIIP & 0.073911 & 0.089806 & 0.823003 & 0.0005 \\
\hline \multicolumn{5}{|l|}{ Variance Equation } \\
\hline $\mathrm{C}$ & 0.120671 & 0.001016 & 0.659740 & 0.0194 \\
\hline $\operatorname{RESID}(-1)^{\wedge} 2$ & 3.723729 & 0.795658 & 4.680065 & 0.0000 \\
\hline R-squared & 0.612086 & \multicolumn{2}{|c|}{ Mean dependent var } & 0.030002 \\
\hline Adjusted R-squared & 0.636183 & \multicolumn{2}{|c|}{ S.D. dependent var } & 0.192158 \\
\hline S.E. of regression & 0.195603 & \multicolumn{2}{|c|}{ Akaike info criterion } & 1.382210 \\
\hline Sum squared resid & 1.606944 & \multicolumn{2}{|c|}{ Schwarz criterion } & 1.220011 \\
\hline Log likelihood & 34.40862 & \multicolumn{2}{|c|}{ Hannan-Quinn criter. } & 1.322059 \\
\hline Durbin-Watson stat & 2.849485 & & & \\
\hline
\end{tabular}

Source: Secondary Data 


\section{Heteroskedatictiy of Inflation to NIFTY}

The study applied the heteroskedasticity test to know the existence of volatility between the Inflation and Nifty. The following hypothesis has been framed.

Null Hypothesis: No ARCH effect exists between the Inflationand Return prices of Nifty.

Alternative Hypothesis: ARCH effect exists between the Inflation and Return prices of Nifty.

Table 5. Heteroskedatictiy of Inflation to NIFTY

\begin{tabular}{|l|l|l|l|l|}
\hline \multicolumn{4}{|c|}{ Heteroskedasticity Test: ARCH } & \\
\hline F-statistic & 6.135579 & Prob. F(1,41) & 0.2928 \\
\hline Obs*R-squared & 6.158875 & Prob. Chi-Square(1) & 0.2817 \\
\hline
\end{tabular}

Source: Secondary Data

Table 5 signifies that F-statistic calculated value (6.135) seem to be greater than the critical value (4.0012) and p-value seems to be less than 0.05 which indicates that reject the Null Hypothesis and Accept Alternative hypothesis. Thereby confirming that ARCH effect exist between the changes in Inflation with Return price of Nifty.

Figure 3. Residual Graph of Inflation to Nifty

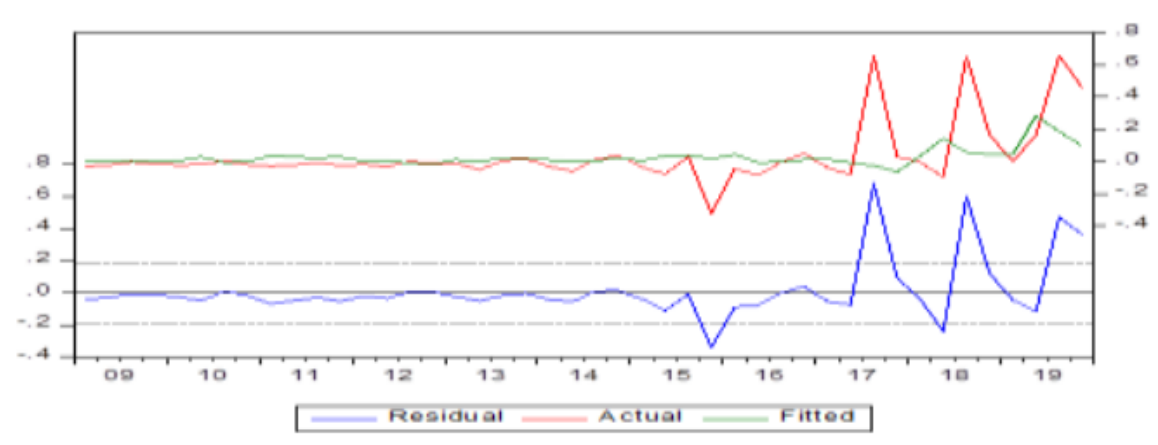

Source: Secondary Data

Figure 3 depicts the change in Inflation on return price of Nifty for the period of 10 years. It signifies from residual graph that Inflation movement crossed the fitted lines which states that the volatility exists, as the volatility of one cluster is followed by the volatility of other cluster. Hence, the ARCH model can be applied to know the high or low volatility of the nifty with change in Inflation.

Table 6. ARCH effect of Inflation to Nifty

\begin{tabular}{|c|c|c|c|c|}
\hline \multicolumn{5}{|c|}{ Dependent Variable: NIFTY } \\
\hline \multicolumn{5}{|c|}{ Method: ML ARCH - Normal distribution (BFGS / Marquardt steps) } \\
\hline \multicolumn{5}{|c|}{ Sample: 2009Q1 2020Q4 } \\
\hline \multicolumn{5}{|c|}{ Included observations: 48} \\
\hline \multicolumn{5}{|c|}{ Convergence achieved after 23 iterations } \\
\hline \multicolumn{5}{|c|}{ Coefficient covariance computed using outer product of gradients } \\
\hline \multicolumn{5}{|c|}{ Presample variance: backcast (parameter $=0.7$ ) } \\
\hline \multicolumn{5}{|c|}{$\operatorname{GARCH}=\mathrm{C}(3)+\mathrm{C}(4)^{*} \operatorname{RESID}(-1)^{\wedge} 2$} \\
\hline Variable & Coefficient & Std. Error & z-Statistic & Prob. \\
\hline $\mathrm{C}$ & -0.030837 & 0.004807 & -6.415467 & 0.0000 \\
\hline INFLATION & 0.119598 & 0.028153 & 4.248124 & 0.0000 \\
\hline & \multicolumn{2}{|c|}{ Variance Equation } & & \\
\hline
\end{tabular}


Impact of Economic Factors on Market Volatility - A Study of NSE India

\begin{tabular}{|l|l|l|l|l|}
\hline C & 0.000623 & 0.000801 & 0.778031 & 0.0366 \\
\hline RESID(-1)^2 & 3.976976 & 0.715421 & 5.558931 & 0.0000 \\
\hline R-squared & 0.057170 & Mean dependent var & 0.030002 \\
\hline Adjusted R-squared & 0.034722 & S.D. dependent var & 0.192158 \\
\hline S.E. of regression & 0.188792 & \multicolumn{2}{|l|}{ Akaike info criterion } & 1.424889 \\
\hline Sum squared resid & 1.496982 & Schwarz criterion & 1.262690 \\
\hline Log likelihood & 35.34756 & \multicolumn{2}{|l|}{ Hannan-Quinn criter. } & 1.364738 \\
\hline Durbin-Watson stat & 2.857548 & \multicolumn{2}{l}{} \\
\hline
\end{tabular}

Source: Secondary Data

The mean equation table 6 depicts that the p-value is $0.005(<0.05)$ implies that the model is significant. Similarly, variance equation observed to be significant at $5 \%$ level (i.e., p-value is $0.000<0.05)$. The AIC-Akaike data criterion (1.424), the SC-Schwarz criterion (1.262) and the HQC-Hannan-Quinn criterion (1.364) indicated the criterion level of the model. Thereby confirming that the unit increase in Inflation will increase the return price of nifty by 3.976 and concludes that the change in Inflation has a significant effect on the volatility of the return prices of Nifty.

\section{Objective 2: To examine the future movement of the select economic factors, which influences the Nifty Volatility?}

In order to forecast the future moment of the dependent variable such as GDP, IIP and Inflation for the next 3 year, ARIMA model has been applied. Below result signifies the ARIMA model.

Table 7. ARIMA Forecasting for GDP, IIP and Inflation

\begin{tabular}{|c|c|c|}
\hline $\begin{array}{l}\text { Automatic ARIMA } \\
\text { Forecasting }\end{array}$ & $\begin{array}{l}\text { Automatic ARIMA } \\
\text { Forecasting }\end{array}$ & $\begin{array}{l}\text { Automatic ARIMA } \\
\text { Forecasting }\end{array}$ \\
\hline $\begin{array}{l}\text { Selected dependent variable: } \\
\text { D(GDP) }\end{array}$ & Selected dependent variable: IIP & $\begin{array}{l}\text { Selected dependent variable: } \\
\text { INFLATION }\end{array}$ \\
\hline Sample: 2009Q1 2020Q4 & Sample: 2009Q1 2020Q4 & Sample: 2009Q1 2020Q4 \\
\hline Included observations: 48 & Included observations: 48 & Included observations: 48 \\
\hline Forecast length: 12 & Forecast length: 12 & Forecast length: 12 \\
\hline $\begin{array}{l}\text { Number of estimated ARMA } \\
\text { models: } 25\end{array}$ & $\begin{array}{l}\text { Number of estimated ARMA } \\
\text { models: } 25\end{array}$ & $\begin{array}{l}\text { Number of estimated ARMA } \\
\text { models: } 25\end{array}$ \\
\hline $\begin{array}{l}\text { Number of non-converged } \\
\text { estimations: } 0\end{array}$ & $\begin{array}{l}\text { Number of non-converged } \\
\text { estimations: } 0\end{array}$ & $\begin{array}{l}\text { Number of non-converged } \\
\text { estimations: } 0\end{array}$ \\
\hline $\begin{array}{l}\text { Selected ARMA model: } \\
(3,3)(0,0)\end{array}$ & $\begin{array}{l}\text { Selected ARMA model: } \\
(0,0)(0,0)\end{array}$ & $\begin{array}{l}\text { Selected ARMA model: } \\
(1,0)(0,0)\end{array}$ \\
\hline AIC value: -0.905799950868 & AIC value: 0.636803658288 & AIC value: -0.231567288268 \\
\hline
\end{tabular}

Source: Secondary Data

Table 7 represents the method used to select the appropriate ARMA model, for this the model considered Akaike Information criterion to find out the best model or optimal model. The result signifies that GDP is fit at $(3,3)(0,0)$ position of forecasting value, IIP is fit at $(0,0)(0,0)$ and inflation seem to be fit at $(1,0)(0,0)$. This position or index values are used to estimating the moving average for the next 3 year (i.e., 2020 to 2022). 


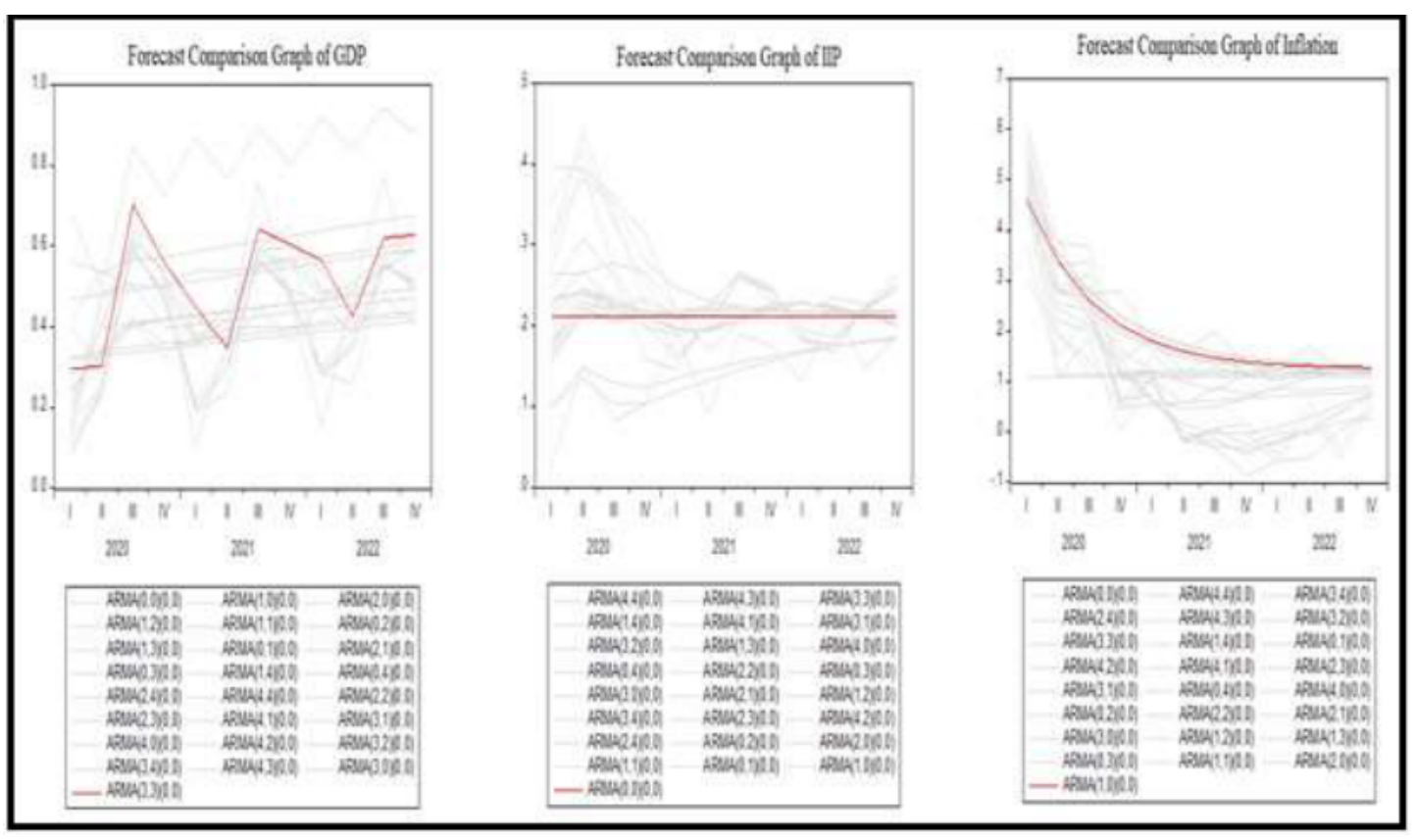

Figure 4. Foresting of GDP, IIP and Inflation with ARIMA

Source: Secondary Data

The above figure 4 Forecast Comparison Graph shows that each of the 25 models picked up the same cyclical patterns and resembles similar nature to the moving average price of the economic variable. In which red line represents the optimal or best fit line to predict the upcoming 3 years. It is found that GDP is fit at $(3,3)(0,0)$ position of forecasting value, IIP is fit at $(0,0)(0,0)$ and inflation seem to be fit at $(1,0)(0,0)$. The above red line signifies that upcoming 3 years, Volatility of GDP is observed to be higher than the IIP and Inflation. Whereas, IIP seem to be constant and Down trend had shown by inflation in next upcoming years. Hence it stated that among economic variable GDP is observed to be high impact on the nifty prices in future than other variables.

\section{FINDINGS OF THE STUDY}

- The following are the findings have been derived with the statistical results for the framed objectives. They are,

- ARCH test estimated that, coefficient value of GDP, IIP and Inflation are 4.40, 3.73 and 3.97 respectively and examined that economic factor had significant effect on the volatility of Market return (Nifty).

- Residual graph represent that with the fluctuation in growth rate of GDP had shown significant high volatility effect on the return price of Nifty.

- It is found that upcoming 3 years (2020 to 2022), Volatility of GDP is observed to be higher than the IIP and Inflation.

- It also examined from ARIMA model that IIP had constant change in next 3 years and down trend had shown to inflation in next upcoming 3 years.

\section{CONCLUSION}

The present study has been focused on the impact of economic factors on the equity market volatility. The study has considered the secondary data of NSE India base index - Nifty along with the economic factors of GDP, IIP and Inflation from the period of 2009-10 to 2018-19 
years. The study applied the ARCH model for the examination of Nifty volatility with the effect of select economic factors and the result indicated that the GDP is having the higher impact on the Nifty volatility. The study applied the ARIMA and the result indicated that the IIP will change and Inflation is expected to move downtrend. There is a need to do research in this area by considering the economic factors impact on the select sectoral indices volatility of the Indian equity markets, so that the investors fraternity will take inform decision.

\section{REFERENCES}

[1] Kaan Celebi et. al (2019):

[2] Ashwani et. al (2018):

[3] Romi Sainy (2016):

[4] Kausik Chaudhuri (2009):

[5] John J Binder (2006): 